\title{
amsterdamlawforum
}

\section{POLICING PROTEST IN THE POST-FORDIST CITY}

Paul A. Passavant*

\section{Introduction}

Prominent scholarship focusing on the question of freedom of speech in the context of urban space discusses how the privatisation of public space circumscribes the exercise of the right of freedom of speech. ${ }^{1}$ If space remains public, and the place that the speaker wishes to speak is determined to be a 'public forum' then the speaker's rights to freedom of speech and assembly, protected by the First Amendment to the United States Constitution, are on their strongest grounds. Thus, governmental regulation of a speaker or speech is presumptively invalid. Even if the state burdens a speaker with a 'time, place or manner' regulation, such a regulation must be justified without reference to the content of the speech, be narrowly tailored to the furtherance of a significant governmental interest, and leave open ample alternative channels for expression - in other words, the state bears a significant burden of justification. ${ }^{2}$ With formerly public space privatised, however, private security can control the uses of property in accordance with the wishes of the property owner. With the privatisation of public space, the landscape of rights shifts to disenfranchise the potential speaker while protecting the power of the owner to control the environment for the owner's purposes.

Over the last half of the twentieth century, cities in the United States lost jobs and population to the suburbs. New retail also fled the city to the suburbs and created the shopping mall to recapture the suburban consumer market. With growing suburbanisation, the proliferation of shopping malls in suburbia, and being left with a population that was increasingly impoverished, cities suffered a 'fiscal crisis'. ${ }^{3}$ As federal aid to cities was slashed, cities were forced to become more 'entrepreneurial' The shopping mall, a prominent cause of the demise of the city, became its hope for salvation. To be sure, using the shopping mall for the purpose of urban redevelopment entailed the privatisation of public space that scholars criticise. Yet of greater significance is the way that the mall became more

\footnotetext{
* Paul A. Passavant is an Associate Professor and Chair of the Department of Political Science at Hobart and William Smith Colleges. He is the author of No Escape: Freedom of Speech and the Paradox of Rights' (New York University Press, 2002), editor (with Jodi Dean) of 'Empire's New Clothes: Reading Hardt and Negri' (Routledge, 2004), and the author of numerous articles in law and political theory. The author would like to thank Jodi Dean for reading an earlier draft of this article and Emily Corcione for research assistance.

${ }^{1}$ L. Staehel \& D. Mitchell, The People's Property, New York: Routledge 2008, chap. 4 esp.; M. Kohn, Brave New Neighborhoods: The Privatization of Public Space, New York: Routledge 2004.

2 Clark v. Community for Creative Non-Violence, 468 US 288 (1984).

${ }^{3}$ R. Alcaly \& D. Mermelstein, eds. The Fiscal Crisis of American Cities, New York: Vintage 1977.
} 
than a physical locale. The mall became a logic or mentality for the governance of urban space. The norms governing control of the social environment in a shopping mall came to govern the policing and control of public urban space as well as private commercial space. In other words, while the loss of public spaces to privatisation is troubling, still more troubling is the way that public space in the city is coming to be governed.

In this paper, I will examine lower level court decisions regarding the right to protest over the last ten years, putting them in the context of the shift in urban political economy from Fordism to the city's neoliberal and postFordist response to the urban fiscal crisis. As these micro-level legal actions accumulate, we can see a neoliberal juridical regime taking shape. Within this neoliberal juridical regime, I contend that the right to free speech is becoming disarticulated from the practice of democracy. Freedom of speech, then, comes to mean that the state must allow a group to 'express' itself. The state may manage, however, the place that this expression occurs so that it does not disrupt the mega-events that the city uses to market itself in the increasingly global inter-urban competition for tourism. The state may also manage the right of free speech so that the exercise of this right does not disturb the state's efforts to produce an environment conducive to the consumption of culture. Speech is kept from being disorderly-from disordering the contemporary post-Fordist environment. Instead, it is reduced to becoming one more zoned form of entertainment, spectacle, or simulacrum as it enters the post-Fordist economy of symbolic production.

\section{Urban Fiscal Crisis}

Two associated developments during the last quarter of the twentieth century have deeply influenced the context and conduct of urban governance-the decline of Fordism and the rise of post-Fordism, on the one hand, and the rise of neoliberalism, on the other. Fordism refers to mass production, mass consumption, a social welfare state, and a steadily improving aggregate national political economy valorising production. Post-Fordism refers to the loss of manufacturing in cities, economies demanding flexible labor and justin-time production for segmented market niches, and the valorisation of consumption. Neoliberalism is closely associated with post-Fordism. Neoliberalism privileges privatisation, market-based logics, and is antagonistic towards the appearance of 'state intervention' in markets or state responsibility in the areas of social welfare and public health. Such logics justify slashing the welfare state, which in turn forces labor to accept a more 'flexible' position. ${ }^{4}$

At the end of World War II, most white-collar and manufacturing jobs in the United States were located in cities. Federal policy to construct an extensive

4 A. Amin, 'Post-Fordism: Models, Fantasies and Phantoms of Transition', in Post-Fordism: A Reader, ed. A. Amin, Cambridge: Blackwell 1994, pp. 1-39; D. Harvey, A Brief History of Neoliberalism, New York: Oxford University Press 2005, pp. 2-3. 
interstate highway system, however, hurt cities. Highways allowed whitecollar workers to keep jobs located in the city, but move to the suburbs, thereby diminishing the property base used for infrastructural upkeep. Highways, by facilitating the growth of trucking for the transportation of goods, allowed manufacturing to relocate to the suburbs and enjoy horizontal expansion and economies of scale. Additionally, the urban routes of highways tended to be located in 'blighted areas', leading to the removal of black homes and the destruction of stable communities. ${ }^{5}$ Finally, according to urban planner Robert Beauregard, highways "created high value intersections throughout the suburban periphery, and these locations became ideal sites for regional shopping malls". ${ }^{6}$

As cities became poorer and blacker, the growth in the service sector of the United States economy was mainly job growth that occurred in the suburbs. The location of shopping malls provided shoppers and business owners an insulating distance from blacks and urban poverty. By being built on private property mainly accessible by car, these shopping malls could become spaces that were insulated from urban 'problems'. Moreover, in 1976, the Supreme Court refused to enforce its public forum doctrine in the case of shopping malls. This meant that shopping malls could become tightly controlled and policed environments free from political protestors or labor unions, which could picket department stores more easily when the latter were located in a city's central business district. ${ }^{7}$ Shopping malls, institutionally speaking, were an articulation of authoritarian modes of social control with an incitement of consumption.

The value of the suburban shopping mall was in its very difference from 'the city', as a place of cleanliness, control free from disruption, and most importantly a place free from crime. ${ }^{8}$ The suburban shopping mall represented the negation of the city. Yet from the very moment of the suburban shopping mall's emergence that would come to doom the city, it was already being proposed as the city's salvation. Salvation through negation. As early as 1955, the father of the shopping mall in the United States, Victor Gruen, proposed that the shopping mall could be the 'salvation of downtown'. ${ }^{9}$ By 1962, Gruen had established the first downtown enclosed

\footnotetext{
${ }^{5}$ R. Beauregard, When America became Suburban, Minneapolis: University of Minnesota Press 2006, pp. 84-85; B. Frieden \& L. Sagalyn, Downtown, Inc: How America Rebuilds Cities, Camridge: MIT Press 1989, pp. 20-22, 28-30.

${ }^{6}$ Beauregard 2006, supra note 5, p. 85.

7 P. A. Passavant, 'The Governmentality of Consumption', Interventions (Vol. 3) 2004, pp. 381-400.

8 The relevant differences of the suburban shopping mall in comparison to a city's downtown are described by Frieden \& Sagalyn 1989, supra note 5, p. 66; see also Passavant 2004, supra note 7, p. 394 (discussing New Jersey Coalition against the War in the Middle East v. J.M.B. Realty Corp. 138 NJ 326 [1994]).

'Downtown Needs a Lesson from the Suburbs', Business Week, October 22, 1955, p. 64.
} 
urban shopping mall-Midtown in Rochester, New York. ${ }^{10}$ Even with Gruen's lead, however, other mall developers were slow to follow. In 1973, the largest shopping mall developer in the United States, Edward DeBartolo, advised other mall developers to stay in the suburbs since people stay away from the downtown because of 'danger'.11

By the end of the 1970s and into the 1980s, however, mall developers turned to cities and cities turned to mall developers. On the one hand, after a surge in suburban mall development in the first half of the 1970s, malls began to saturate the suburban market. On the other, cities were forced to become more 'entrepreneurial' to address the loss of the middle class, deindustrialisation, and severe reductions in federal aid in conjunction with state-level restrictions on revenue-raising (such as the referenda passed in California and Massachusetts limiting property tax increases). ${ }^{12}$ To respond, cities began thinking about ways to raise revenue from those who did not live in the city, but who might be persuaded to visit the city - to shop or as a tourist, for example.

In the process of constructing and marketing this 'fantasy city', through hosting and marketing mega-events, for example, cities also constructed 'tourist enclaves' or a 'tourist bubble'-a zone sanitised of urban disorder, with security, and more importantly, signs of security or an aesthetics of security, to make visitors feel safe. ${ }^{13}$ Not only did crime need to be prevented in order to lure the middle class back to the city as tourists or shoppers, but the perception of danger or disorder needed to be controlled. ${ }^{14}$ The symptoms of the urban crisis needed to be rendered invisible within the 'analogous' or 'fantasy' city produced for visitors. ${ }^{15}$ Therefore, the emerging police practices coinciding with post-Fordist urban redevelopment strategies were 'zerotolerance' or 'quality of life' policies that targeted not only actual crime, but any signs of disorder or poverty to signal to shoppers and tourists that they were secure and in a controlled setting. The city, which had achieved a reputation as 'dangerous', needed to become rebranded as 'fun'. Quality of

${ }^{10}$ V. Gruen, The Heart of Our Cities: The Urban Crisis, New York: Simon and Schuster 1964, pp.300ff.

${ }^{11}$ Frieden \& Sagalyn 1989, supra note 5, p. 5.

12 This is not a phenomenon limited to the United States. See T. Hall and P. Hubbard, eds. The Entrepreneurial City: Geographies of Politics, Regime, and Representation, New York: John Wiley \& Sons 1998.

13 J. Hannigan, Fantasy City: Pleasure and Profit in the Postmodern Metropolis, New York: Routledge 1998; D. Judd, 'Constructing the Tourist Bubble', in The Tourist City, eds. D. Judd \& S. Fainstein, New Haven: Yale University Press 1999, pp. 35-53; D. Judd, 'Visitors and the Spatial Ecology of the City', in Cities and Visitors: Regulating People, Markets, and City Space, eds. L. Hoffman, S. Fainstein, and D. Judd, Malden: Blackwell Publishing 2003, pp. 23-38.

${ }^{14}$ C. Parenti, Lockdown America: Police and Prisons in the Age of Crisis, New York: Verso 1999, pp. 100-101.

${ }_{15}$ T. Boddy, 'Underground and Overhead: Building the Analogous City', in Variations on a Theme Park: The New American City and the End of Public Space, ed. M. Sorkin, New York: Hill and Wang 1992, pp. 123-153. 
life (QOL) policing was integral to this process. ${ }^{16}$ In other words, authoritarian modes of policing are the flip-side to the celebrated fun city of consumption, from the use of militarised policing to clear the poor or homeless from a space being readied for redevelopment, to a 'zero-tolerance' attitude toward visible signs of minor disorder by cities implementing the QOL policing paradigm. ${ }^{17}$

This effort to make cities into producers of entertainment means that cities are aggressively marketed and promoted through the logic of branding in the inter-urban competition for revenue from tourism. This means, ironically, that cities become more like each other even as they are driven to become 'distinctive' from each other for their branding strategy. Increasingly, then, we see a process of mutual fertilisation between entertainment corporations like Disney and urban planning-a process to which many refer as the 'Disneyfication of urban space'. Our two primary metaphors for understanding processes of urban redevelopment in the United States - the mall and Disney - in effect say the same thing.

The mall pervades urban planning so deeply that even if a physical mall is not built, its principles are applied to the development of city space. Thus, the mall maintains a conceptual predominance, even if the growth rate of actual malls has stalled. As designer John McMorrough has written, "the city of shopping is a normalisation of the logic of shopping as embodied in the mall into the very idea of urbanity.... The city itself is the medium for post-mall shopping."18 While Walt Disney found the work of Victor Gruen to be influential, Disney himself was significant as an inspiration for shopping mall designers and the urban redevelopment projects of the 1970s and 1980s drawn up by those mall designers. Architectural critic Paul Goldberger has praised Disneyworld as "perhaps the most important city planning laboratory in the U.S.", and festival marketplace designer James Rouse called Disneyland the "greatest piece of urban design in the United States", in a 1963 speech. ${ }^{19}$ Since the tourist city reconfigures its infrastructure to provide themed experiences for those who are not residents of the city, the fact that nobody lives in Disneyworld makes this theme park an even more compelling model for understanding the city today than when Rouse gave his speech 40 years ago. As the former head of Disney's movie division has

\footnotetext{
${ }^{16}$ For a discussion of quality of life policing in the context of New York City, including the observation that QOL policing was pioneered by Mayor Dinkins, though perfected under Mayor Giuliani, see A. Vitale, City of Disorder: How the Quality of Life Campaign Transformed New York Politics, New York: New York University Press 2008.

${ }^{17}$ For a discussion of the battle between the New York City police and the homeless over Tompkins Square Park, see N. Smith, The New Urban Frontier: Gentrification and the Revanchist City, New York: Routledge 1996, pp. 218ff., and passim. A. Amin, 'Collective Culture and Urban Public Space', City (Vol. 12) April 2008, pp. 5-24, then, celebrates the city of consumption with little regard to how it is inextricably linked to punitive forms of policing. ${ }^{18}$ John McMurrough, 'City of Shopping', Project on the City: The Harvard Design School Guide to Shopping, eds. C. J. Chung, et. al., Köln, New York, etc.: Taschen 2001, pp. 183, 202.

${ }^{19}$ C. J. Chung, 'Disney Space', Project on the City, supra note 18, pp. 277, 284, 288.
} 
suggested, "Disney World [is] a medium-sized city with a crime rate of zero". ${ }^{20}$

Introducing the city to entertainment-based competition for tourist dollars means malls and Disneyworld are important points of reference for understanding how the city becomes reconstituted as a marketable and brandable place. It also means that the urban landscape comes to replicate geographically the contemporary mentality of marketing. Marketing has shifted from 'mass-marketing' to 'niche marketing', or marketing to clusters. ${ }^{21}$ Likewise, the city now is increasingly re-presented as being constituted by different 'zones'.22 These different zones of the city become distinctively themed for those interested in ethnic neighbourhoods, museums, 'culture', sports, or gay lifestyles. The zone is how we think, move through, and organise the neoliberal, post-Fordist city.

\section{Erogenous Zoning: Containing Secondary Effects}

Coinciding with the urban fiscal crisis, and the way that neoliberalism has superceded the social state or social welfare mentalities of governance, the United States Supreme Court's jurisprudence in the area of free speech also shifted. In its approach to the regulation of sexual expression, for instance, the Supreme Court developed legal tools that lower courts would be able to use, whether for the Disneyfication of public space or to assist a city's handling of mega-events that in turn can help to promote a particular branded identity for a city. ${ }^{23}$ We can summarise these changes as a shift from a juridical model of censorship to one of containment. ${ }^{24}$

Until its last effort, in 1973, to define obscenity - sexual expression so prurient and offensive that it can be legally criminalised without violating the First Amendment - the Supreme Court operated within a model of censorship. ${ }^{25}$ This juridical framework tried to define with some specificity the expressive act that could be censored for the good of society. ${ }^{26}$ All other forms of expression were protected equally under the First Amendment. ${ }^{27}$

20 Michael Sorkin, 'See you in Disneyland', Variations on a Theme Park, supra note 15, pp. 231.

${ }^{21}$ Lizabeth Cohen, A Consumers' Republic, New York: Knopf 2003, chap. 7.

22P. Marcuse, “Dual City”: A Muddy Metaphor for a Quartered City', International Journal of Urban and Regional Research*(Vol. 13) 1989, pp. 697-708; P. Marcuse, 'Not Chaos, but Walls: Postmodernism and the Partitioned City', in Postmodern Cities and Spaces, eds. S. Watson and K. Gibson, Cambridge, MA: Blackwell 1995, pp. 243-253.

23 S. Body-Gendrot, 'Cities, Security, and Visitors: Managing Mega-Events in France', Cities and Visitors, supra note 13, pp. 39-52.

24 P. A. Passavant, 'Governing Sexuality: The Supreme Court's Shift to Containment', Between Law and Culture: Relocating Legal Studies, eds. D. T. Goldberg, M. Musheno, and L. Bower, Minneapolis: University of Minnesota Press 2001.

25 Ibid.

${ }^{26}$ Chaplinsky v. New Hampshire, 315 US 568 (1942).

27 Grayned v. Rockford, 408 US 104 (1972); Police Department v. Mosley, 408 US 92 (1972). 
After 1973, though, the Supreme Court largely put to one side the effort to define obscenity.

After 1973, the Supreme Court has become increasingly tolerant of efforts to regulate non-obscene speech that is considered 'indecent', where the latter is undefined legally. Indecent but non-obscene sexual expression may not be totally censored. Its perceived detrimental effects, however, may be regulated and contained through various zoning strategies. Broadcasters, for example, can be forced to air programming with indecent speech during hours when children are unlikely to be listening or watching. Indecent speech is not censored, but zoned to particular time-slots. Justice Stevens makes the analogy to zoning explicit in his Federal Communications Commission v. Pacifica opinion. There, Stevens likened indecent speech to a nuisance, the location of which can be zoned by a locality's land-use regulations. A nuisance, he argued, "may be merely a right thing in the wrong place,--like a pig in the parlor instead of the barnyard." He continues: "We simply hold that when the Commission finds that a pig has entered the parlor, the exercise of its regulatory power does not depend on proof that the pig is obscene". ${ }^{28}$ The value of such regulations continues to be expressed in accordance with a zoning logic. As Justice Scalia has written in a more recent case involving Federal Communications Commission (FCC) regulations, they give "conscientious parents a relatively safe haven for their children." 29

While thinking in terms of niches or zones is a more general mentality in contemporary neoliberal society, it plays a particularly important role in the way that cities have sought to respond to the urban crisis. Beginning in the mid-1970s, the Supreme Court developed jurisprudence that would allow city governments to move sexually oriented businesses out of districts targeted for post-Fordist redevelopment. We can refer to this as the Court's 'secondary effects' jurisprudence.

In a series of cases including Young v. American Mini Theatres (1976), Schad v. Mt. Ephraim (1981), Renton v. Playtime Theatres (1986), Barnes v. Glen Theatre (1991), and Erie v. Pap's A.M. (2000), the Supreme Court created a body of legal doctrine allowing for the containment, but not the censorship, of sexually oriented businesses. ${ }^{30}$ In these cases, the Court allows for the regulation of nude dancing, and other 'adult' oriented businesses, through zoning laws or city ordinances. These strategies of governance may not

${ }^{28}$ Federal Communications Commission v. Pacifica, 438 US 726 (1978), quoting in part Village of Euclid, Obio v. Ambler Realty Co., 272 US 365 (1926). Though not reaching the constitutional question, the Supreme Court sustained the FCC's decision to increase significantly the fines for violating these decency regulations against a legal challenge based on the Administrative Procedures Act in Federal Communications Commission v. Fox Television Stations, 556 US (2009)

(slip op. online: www.supremecourtus.gov, (accessed November 14, 2009)).

${ }^{29}$ FCC v. Fox Television (2009), supra note 28, p. 26.

${ }^{30}$ Young v. American Mini Theatres, 427 US 50 (1976); Schad v. Mt. Ephraim, 452 US 61 (1981); Renton v. Playtime Theatres, 475 US 41 (1986); Barnes v. Glen Theatre, 501 US 560 (1991); Erie v. Pap's A.M., 529 US 277 (2000). 
directly forbid any such establishment to locate within a city. ${ }^{31}$ They may, however, disperse such businesses throughout a city, cluster them within a particular zone, or regulate their proximity to homes, schools, or churches. ${ }^{32}$ Dancers may also be required to wear minimal clothing, such as 'pasties' or a 'g-string'. 33

In this regulatory regime, sexual expression is not censored. Instead, because various 'secondary effects' of urban disorder or crime are said to be mysteriously correlated with the sex industry, the Supreme Court allows such zoning regulations aimed at these businesses in order to target their secondary effects. If secondary effects were caused by sexual expression, then these regulations would be acts of censorship violating the First Amendment since they would be targeting speakers (e.g., nude dancers or establishments promoting such expression) based on the content of their speech. To withstand First Amendment scrutiny, then, these secondary effects must be understood as being simply correlated with sexually oriented businesses. As Justice Souter explains in his concurring opinion in Barnes v. Glen Theatre, a case involving nude dancers at the 'Kitty Kat Lounge' in South Bend, Indiana: men are not led directly by sexual expression to commit crime. It is simply the case that a "concentration of crowds of men predisposed to such activities" tends to congregate in the vicinity of such establishments. ${ }^{34}$

In this legal view, no message is censored, and no willing viewer or recipient of the message is prevented from gaining access to it. Merely the manner of expression is regulated with the requirement that dancers wear pasties and gstrings, as with Indiana's anti-public nudity statute, but not the erotic message of the speech act. Or, the place where those seeking to make available sexually oriented expression to willing consumers is regulated through zoning, as with Detroit's 'Anti-Skid Row Ordinance'. ${ }^{35}$ In essence, the Court's secondary effects cases constitute a subfield of the Court's broader time, place, and manner jurisprudence in its effort to provide local governments legal tools to contain the effects thought to be associated with indecent expression in order to protect, or begin to develop, a particular 'quality of life'. 36

One context for this policy to 'clean up' the city by removing sexually oriented businesses from particular areas is the changed racial status of many cities in the United States by the 1970s which, in turn, encouraged a racial

31 Schad v. Mt. Ephraim (1981), supra note 30.

32 Young v. American Mini Theatres (1976), supra note 30; Renton v. Playtime Theatres (1986), supra note 30.

33 Barnes v. Glen Theatre (1991), supra note 30; Erie v. Pap's A.M. (2000), supra note 30.

34 Barnes v. Glen Theatre (1991), supra note 30, Souter concurring.

${ }^{35}$ Barnes $v$. Glen Theatre (1991), supra note 30; Young v. American Mini Theatres (1976), supra note 30, Powell concurring.

36 Renton v. Playtime Theatres (1986), supra note 30. 
valence in the way that cities were represented in urban policy discourse. ${ }^{37}$ Detroit, for example, which was the city involved in Young v. American Mini Theatres, flipped demographically over the course of the twentieth century from being a city that was 91 percent white in 1940 to becoming a city that, by 1980 , had become 63.1 percent black. ${ }^{38}$ Another context that I wish to emphasise here, however, is the context of urban fiscal crisis and shifts in urban political economy. Justice Powell brings both together in a way that anticipates the zero-tolerance, QOL policing strategy that would become so closely associated with New York City in the 1990s during Rudy Giuliani's terms as mayor. In his concurring opinion, Powell describes the governmental interest in the zoning regulation as the means to protect "that sometimes difficult to define concept of quality of life." This means addressing the danger that "sections of a modern city quickly can deteriorate into an urban jungle with tragic consequences to social, environmental, and economic values." 39 Detroit's 'Anti-Skid Row Ordinance' legitimately sought to protect certain commercial areas from deterioration, and neighbourhoods from the deleterious effects of sexually oriented businesses that could lead to the area becoming blighted.

As is well known, the Walt Disney Corporation is central to the redevelopment of the $42^{\text {nd }}$ Street/ Times Square district of New York City. Once a site for movie theatres showing pornography, stores selling pornography, and clubs with nude dancers, today, Times Square is thoroughly 'Disneyfied'. Parents can be seen at night pushing children in strollers, teens can be seen snapping cell-phone photos of themselves in this media zone, the 24 hour sports news network ESPN (owned by Disney corporation) has a themed restaurant in Times Square, and Disney Channel star Miley Cyrus could be seen performing in Times Square on New Year's Eve, 2007. As Frank Roost notes, Times Square is perhaps the "best-known example of entertainment-driven urban redevelopment". ${ }^{40}$

According to Roost, before renovating the New Amsterdam Theatre, Disney negotiated not only financial incentives from the state, but the "social transformation of Times Square" so that Disney's family-friendly brand image would not be compromised. In effect, Disney required as a condition for its investment that the city be changed to fit Disney's brand. Mayor Rudy

37 P.A. Passavant, No Escape: Freedom of Speech and the Paradox of Rights, New York: New York University Press 2002, chap. 6; R. Beauregard, Voices of Decline: The Postwar Fate of US Cities, Cambridge: Blackwell 1993.

${ }^{38}$ R. C. Hill, 'Crisis in the Motor City: The Politics of Economic Development in Detroit', Restructuring the City: The Political Economy of Urban Redevelopment, revised edition, eds. S. Fainstein, et. al., New York: Longman 1986, pp. 91-92.

39 Young v. American Mini Theatres (1976), supra note 30, Powell concurring.

${ }^{40}$ F. Roost, 'Synergy City: How Times Square and Celebration are Integrated into Disney's Marketing Cycle', Retbinking Disney: Private Control, Public Dimensions, eds. M. Budd \& M. Kirsch, Middletown, CT: Wesleyan University Press 2005, p. 261. 
Giuliani assured Disney executive Michael Eisner that the porn would be removed. ${ }^{41}$

A Department of City Planning (DCP) Study conducted in late 1993 and an April 1994 study conducted by the Times Square Business Improvement District, among other studies, found 'negative secondary impacts', including crime, diminished property values, and a 'perceived decline in the community character', to be associated with the presence of X-rated businesses. Based on this information, City Council passed permanent zoning restrictions on adult entertainment October 25, 1995 pursuant to the recommendations of the DCP. These regulations forced 'adult' commercial establishments, bookstores, theatres, and eating or drinking establishments, to relocate to more peripheral commercial and industrial zones in the city. It also required that such an establishment not be located within 500 feet of any 'school, daycare center, or house of worship, nor within 500 feet of the edge of most residential areas... nor within 500 feet of any other adult establishment'. These zoning regulations were sustained as constitutional zoning regulations targeting negative secondary effects, rather than a particular viewpoint, in federal district and appeals courts decisions. ${ }^{42}$ These rulings cleared the way for the removal of substantial numbers of sexually oriented businesses from Times Square to make this zone 'Disney friendly'.

Zoning based on secondary effects of sexual expression meshes with the 'zero-tolerance', QOL policing for which Giuliani and his police commissioner, William Bratton, are famous. QOL policing addresses not only actual crime, but also signs of economic distress and disorder, such as panhandlers, homeless, and 'squee-gee men'. ${ }^{43}$ Likewise, the negative secondary effects cited to justify the removal of sexually oriented businesses from Times Square include diminished property values (a perception) and a 'perceived decline in community character'. Like QOL policing, secondary effects rules are oriented towards creating and governing the aesthetic environment for a given zone - a project and projection that goes far beyond crime control since non-obscene sexual expression is a protected right under the First Amendment. They are part of an overall strategy of governance to produce post-Fordist urban space to market the city to the nonresident tourist, visitor, or suburban shopper. Like the ESPN Zone or Disney policies, these strategies of urban governance are acts of aesthetic or affective production in their efforts to control space. Now, like Disneyworld, Times Square is a family-friendly tourist destination.

Both Disney and the post-Fordist city benefit from Disney being embedded in Times Square. On the one hand, Disney has persuaded New York City to

\footnotetext{
${ }^{41}$ Idem, p. 270.

42 Adele Buzzetti d/b/a Cozy Cabin and Vanessa Doe v. City of New York 1997 US Dist LEXIS 4383 (1997); Adele Buzzetti d/b/a Cozy Cabin and Vanessa Doe v. City of New York, 140 F. 3d 134, 1998 US App. LEXIS 5609 (1998) (cert. denied 1998 US LEXIS 4846 [1998]).

43 Vitale 2008, supra note 16.
} 
turn off streetlights along a parade route to help Disney manage an event to produce a viewing experience as spectacular as it would be if it had been held in one of Disney's privately controlled theme parks. ${ }^{44} \mathrm{On}$ the other hand, Disney staged the premiere of its movie "Pocahontas" on the Great Lawn in Central Park. The crowd was estimated to be between 70,000 (police) and 100,000 (Disney). This movie premiere innovated the use of ticketing a public event on the Great Lawn, as prior mass concerts on the Great Lawn have been open to the public on a first come, first served basis. Some New York City residents grumbled, however. One Upper West Side resident complained about being excluded from the park despite having paid for a permit to use an athletic field. City officials, though, were pleased. An assistant commissioner in the Parks Department who helped plan the event gushed, "Here's Disney attracting family to Central Park". According to Giuliani, although the city would incur costs from the staging of 'Pocahontas', the event would help to promote New York City since the city would have shown "the largest movie premiere in history in the world's greatest park in the world capital city". This mega-event was expected to bring "tens of millions of dollars to the city in direct and indirect revenues", in Giuliani's view. 45 The post-Fordist city uses mega-events to produce a brandable image, and to market itself in the global inter-urban competition for revenue deriving from tourism. In so doing, however, it redirects resources and infrastructure away from city residents and towards potential visitors.

\section{Policing Protest}

Under First Amendment legal doctrine, the state's power to restrict communication is most circumscribed when speech occurs in a 'public forum'. Traditional public fora include public parks, streets, and sidewalks. ${ }^{46}$ Over the last ten years, however, when protesters have sought to use traditional public fora to express grievances, such fora have been closed to them for the purpose of maintaining an aesthetic environment free from disruption to incite the consumption of culture or to enhance the experience of those visiting the post-Fordist city and its production of entertaining experiences or mega-events. In other words, traditional public fora in the city are coming to be governed much like a shopping mall or Disneyworld.

\section{III.1 This is Not a Park}

The way that a post-Fordist urban aesthetic suffocates the right to protest is illustrated by an appeals court decision in a case involving a labor union representing hotel and restaurant workers and the City of New York and the

${ }^{44}$ Roost 2005, supra note 40, p. 270.

${ }^{45}$ F. Lee, 'Thousands Jam Disney's Newest Park to See "Pocahontas", New York Times, June 11, 1995, p. 37 (Sec. 1).

46 Hague v. CIO, 307 US 496 (1939); Perry Education Association v. Perry Local Educators' Association, 460 US 37 (1983). 
Lincoln Center for the Performing Arts. ${ }^{47}$ In this case, the union wished to picket and distribute leaflets in the Plaza outside the Lincoln Center to show support for food service workers operating within the Metropolitan Opera. Lincoln Center governs the Plaza for the City and schedules events in the public areas of the Plaza subject to the approval of the Parks Department. In other words, Lincoln Center is the agent for the City Parks Department. The policy of Lincoln Center is to limit approval for the use of the Plaza to those events having a 'performance, entertainment, or artistic component'. The dispute centered on whether Lincoln Center could prevent the Union from picketing and leafleting. According to the appeals court, this regulation of the ability of the right to picket and to leaflet does not violate the First Amendment. Even though the court assumed that the Lincoln Center was a state actor since it managed the Plaza on the city's behalf, it did not find that it was in violation of the First Amendment. Instead, the court of appeals noted that Lincoln Center had governed this space in a generally exclusionary way (such exclusions, however, did not extend to those who sought to eat lunch in the Plaza, nor to those who wanted to soak up some sun there). Through its exclusion of political protesters and union picketers, while allowing musicians, the Lincoln Center sough to create a 'pleasing forecourt at the center of a prominent performance arts complex, to facilitate patrons' passage into the events taking place in the arts buildings, and symbolically to promote the cultural arts for the benefit of the community'. ${ }^{4}$

In this case, despite the fact that authority for this Plaza ultimately fell upon the City, the court upheld the tautological reasoning of the Lincoln Centerbecause others have been excluded it could exclude others in order to produce an aesthetic environment conducive to the consumption of the Center's cultural offerings. The City's Plaza, thus, is understood to be fulfilling an important and complementary function in relation to the Lincoln Center - the production of a controlled environment in order to enhance artistic consumption - that a labor protest on behalf of the service workers employed by the Lincoln Center would only disrupt. For present purposes, however, what is telling about this case is that what would appear to be a traditional or quintessential public forum has been closed (a plaza under the ultimate authority of the Parks Department) to those who wish to protest. In this particular case, the right to protest is circumscribed by an interest in maintaining a particular aesthetic order that will be conducive to the cultural experience for the consumer or the tourist in the Center. Events are limited in the Plaza to those that have a performance, entertainment, or other artistic component. Therefore, in order to preserve the Plaza as an entertainment zone or enclave that promotes the post-Fordist urban production of culture and the consumer's consumption of culture, the labor union protest was rightly regulated, according to the three-judge panel. Thus, the aesthetic

47 Hotel Employees \& Restaurant Employees Union, Local 100 of New York, NY, et. al. v. City of New York Department of Parks and Recreation, et. al. 311 F. 3d 534, 2002 U.S. App. LEXIS 23707 (2002).

48 Idem, pp. 551-552. 
imagination associated with promoting a post-Fordist redevelopment of urban areas by inciting, in part, the consumption of culture in urban areas, means that the exercise of First Amendment rights in a manner that might disrupt this aesthetic order may be regulated.

Organising the workplace was facilitated when businesses were located in cities. Workers could make use of well-traveled sidewalks and streetsquintessential public fora - in order to picket and leaflet. When such businesses moved out to suburban shopping malls, however, they became enclosed within privatised spaces, which presented an additional hurdle to those seeking to unionise these service sector jobs. Today, with such service sector jobs becoming the focus of post-Fordist urban redevelopment, the city itself, as we can see from the example of the attempt to picket the Lincoln Center in the city plaza in front of it, is coming to be governed by the aesthetic imagination of the suburban shopping mall and its norms against disrupting the consumer-oriented environment. Thus, the postFordist 'partition of the perceptible' has detrimental consequences for efforts to unionise the service sector, which is a particularly significant aspect of the post-Fordist economy. ${ }^{49}$

\section{III.2 Criminalising Democratic Strength}

On February 14, 2003, French Foreign Minister Dominique de Villepin made his historic statement against warmongering by the United States and in favor of peace through disarmament at a meeting of the United Nations (UN) Security Council, which was discussing the possibility of authorising the use of force by the United States against Iraq. To coincide with this event, United for Peace and Justice (UFPJ) sought a permit from New York City to parade in front of the United Nations building. New York denied this permit request, and refused to allow the group to parade anywhere in the city. The New York Police Department (NYPD) thus required the group to hold a stationary rally a few blocks from the United Nations building. At the stationary rally, the NYPD forced protesters into barricades forming pens, and used batons, horses, and pepper spray to keep the crowd within the pens. ${ }^{50}$

UFPJ challenged the denial of a parade permit, arguing that to march past the UN building in its direct view was a 'necessary part of the event'. According to the NYPD, however, the march was too large - 100,000 were expected - for the NYPD to secure the safety of the UN headquarters,

49 J. Rancière, Dis-agreement, trans. J. Rose, Minneapolis: University of Minnesota Press 1999 , p. 55.

${ }^{50}$ New York Civil Liberties Union, Arresting Protest: A Special Report of the New York Civil Liberties Union on New York City's Protest Policies at the February 15, 2003 Anti-War Antiwar Demonstration in New York City, New York: New York Civil Liberties Union, April, 2003 (online: www.aclu.org/files/FilesPDFs/nyclu arresting protest1.pdf, accessed November 18, 2009). 
particularly after the attacks of September 11, 2001. Moreover, the NYPD denied UFPJ the right to march anywhere in the city. In response, UFPJ pointed out that numerous other cultural groups of similar size had been allowed to march in New York. The "Dominican Day" parade had 100,000 participants, the 'Puerto Rican Day' parade had 100,000 participants, and the 'Saint Patrick's Day' parade had 120,000 participants. ${ }^{51}$

District Court Judge Barbara Jones disagreed with UFPJ's arguments that the denial of a permit was content-based, hence a violation of the First Amendment. She contended that the UFPJ protest was 'markedly different' from the annual ethnic pride parades which could be planned long in advance. Moreover, she viewed the requirement that the protest be a stationary one, confined within the pens to be merely a regulation on the manner of the speech, and a regulation that was narrowly tailored to security concerns. Thus, it was not considered to be a restriction of the group's ability to communicate that would violate the First Amendment. ${ }^{52}$

Within the post-Fordist city, a political protest that makes manifest the broad strength of popular opposition to state policies now seems to count against the group's First Amendment rights. During the middle of the twentieth century, the Supreme Court recognized that political speech, and speech addressing broad, national questions or public issues, was the speech that should receive the greatest protection under the First Amendment. Now, it seems to receive reduced First Amendment protection when compared to 'large scale cultural and celebratory marches' that would be equally at home in a theme park as in a post-Fordist city like New York where the latter seeks to advertise itself as 'multicultural' and 'diverse'.

Additionally, we can draw a connection between the requirements that dancers wear 'pasties' or a 'g-string' as merely a regulation upon the 'manner' of communication, and forcing UFPJ to hold a stationary rally confined within 'protest pens'. Much like the forced, minimal clothing upon the body of the dancers is a sumptuary marker of state power, being forced into pens not only prevents UFPJ from showing the strength of the people to the rest of the city. It symbolically frames their message within state parameters. Onlookers could be forgiven if they perceived the NYPD's framing of the exercise of popular political strength and democratic aspirations as 'criminalised' within the post-Fordist city.

New York is not alone in this practice. At the 2004 Democratic National Convention (DNC) in Boston, the Boston Police Department (BPD) erected an eight foot wire mesh fence lined with an opaque fabric so protesters could not breach the fence, and so protesters on the outside and dignitaries on the

${ }^{51}$ United For Peace and Justice v. City of New York, 243 F. Supp. 2d 19, 2003 US Dist. LEXIS 1943 (2003). Affirmed: United for Peace and Justice v. City of New York, 323 F. 3d 175, 2003 US App. LEXIS 4526 (2003).

52 Ibid. 
inside could not see each other. A 'Demonstration Zone' (DZ) was created for protesters underneath elevated railroad tracks close to the convention site. The DZ was fenced in, covered with a 'tightly woven mesh fabric', as well as 'looser mesh netting', and covered with looped razor wire. District Court Judge Douglas Woodlock noted that a person of normal height could not stand and carry a sign because of the low height of the girders. The DZ's capacity was approximately 1,000 , but even that number was potentially unsafe and a violation of the city's fire code. Because of these spatial controls, protesters would not be able to reach their intended audience, and Judge Woodlock conceded that the DZ reminded him of "Piranesi's etchings published as Fanciful Images of Prisons", and that the "Overall impression created by the DZ is that of an internment camp". Nevertheless, he sustained the BPD's decision to "coop them all inside a bleak enclosed pen", as the only practical way to maintain a "secured environment". Even with the Judge's concession that the DZ was akin to an "internment camp", this time, place and manner regulation was found to be constitutional in its penning of protesters. Again, democratic actions are displaced and criminalised in the post-Fordist city. ${ }^{53}$

\section{III.3 Maintaining the Environment}

Hosting mega-events, such as sporting events like the Super Bowl, the Olympics, New York's hosting of the premiere of 'Pocahontas', or a major convention like the Democratic or Republican National Conventions, is a significant component of post-Fordist urban production. By hosting such mega-events, cities draw tourists, market themselves through the spectacle to potential visitors, market their capacity to produce a mega-event without disruption, and brand the city in accordance with a particular image. For example, after Hurricane Katrina, New Orleans fast-tracked repairs to its infamous Superdome in order to be able to host major sporting events there like the Super Bowl. In order to prove its mega-event readiness, New Orleans hosted a number of college football bowl games and collegiate basketball tournament games to demonstrate the city's 'rebirth'. Its success in producing these sporting events - at a time when other neighborhoods in New Orleans still looked like "an atomic bomb wiped them off the face of the earth" - was rewarded when its bid to host the 2013 Super Bowl was accepted. ${ }^{54}$

Likewise, to demonstrate New York City's rebirth after the attacks of September 11, 2001, and to 'galvanise the city's tourism industry', Mayor Michael Bloomberg made bids to host the 2012 Olympics, and the Democratic and Republican National Conventions. The bid for the

${ }^{3}$ Coalition to Protest the Democratic National Convention v. City of Boston, 327 F. Supp. 2d 61, 2004 US Dist. LEXIS 14840 (2004). Affirmed: Bl(a)ck Tea Society v. City of Boston, 378 F. 3d 8, 2004 US App. LEXIS 15778 (2004).

${ }^{54}$ P. Thamel, '2 major Bowls will test New Orleans's Recovery', New York Times, April 29, 2007, p. 5 (Section 8). 
Republican National Convention (RNC) was successful. City officials, in collaboration with the White House, worked to showcase New York City by integrating the city's icons as a stage for the re-nomination of George W. Bush for a second administration. Like New Orleans, New York approached the event as a 'coming-out party' after a major disaster, as a generator of economic benefits from the convention, and as an 'indicator' of the city's 'ability to carry on events'. 55

With two wars, the passage of legislation restrictive of civil liberties, and a camp at a United States military base in Guantanamo Bay dedicated to keeping prisoners away from normal legal processes in the United States, numerous political groups planned to protest at the RNC. Of course, such protests could risk disrupting the mega-event of the first RNC after September 11, 2001. Such protests could also disrupt New York's efforts to market the city as returned to the post-Fordist tourist economy as it might raise questions about its readiness to host and produce mega-events.

In National Council of Arab Americans and Act Now to Stop War \& End Racism Coalition v. City of New York, et. al., a federal district court addressed the Council's attempt to get a permit to hold a demonstration of up to 75,000 people on the Great Lawn of Central Park in New York on August 28, 2004 during the RNC. The Great Lawn had symbolic significance for the Council, as did the date of the planned demonstration. The date of the protest was important not only for the fact that it coincided with the RNC and thus presented an opportunity to protest against George W. Bush's policies in the Middle East. The date also fell on the 41st anniversary of the 1963 March on Washington led by Martin Luther King, Jr., and therefore commemorates the struggle for civil rights. The Great Lawn, according to the Council, is important not only because it could accommodate a demonstration of the size that the Council expected and that it was a large, unconfined, family friendly mass rally venue. The Great Lawn is important because it is a place where mass assembly has taken place in the past, it represents the heart and soul of New York as the flagship for where people gather, and as such, it symbolises a link of centrality, hence acceptance and equality for the Arab American people. Since many major rallies had been held on the Great Lawn, such as the 1982 anti-nuclear rally, an anti-apartheid rally in 1986, a Gay Pride rally in 1989, and Earth Day in 1990, assembly on the Great Lawn is part of the political message. ${ }^{56}$

55 M. Cooper, 'Look Beyond City's Fiscal Woes, Mayor Tells a Congregation', New York Times, November 11, 2002, p. 5 (Section B); R. Archibold, 'All of New York's a Stage for the G.O.P. Convention', New York Times, May 26, 2003, p. 5 (Section B).

${ }^{56}$ National Council of Arab Americans and Act Now to Stop War \& End Racism Coalition v. City of New York, et. al. U.S. Dist Court for the Southern District of New York, 331 F. Supp. 2d. 258, 2004 U.S. Dist. LEXIS 16628 (August 23, 2004), pp. 262-263; R. Rosenzweig \& E. Blackmar, The Park and the People: A History of Central Park, Ithaca: Cornell University Press 1992 , p. 519. 
The City of New York, however, sought to prevent the rally in order to protect the Great Lawn from possible damage. After years of what was now considered to be 'overuse', the Lawn was restored in 1997 at a cost of over $\$ 18$ million. Consisting of over twelve acres of 'hearty' Kentucky blue grass, soil engineered to resist compaction, sub-surface drainage lines, irrigation lines, pop-up sprinklers, and eight baseball diamonds, the Great Lawn is under a comprehensive management program by the City Parks Department, devised in consultation with turf specialists, engineering, and architectural firms. This plan limits large events on the Lawn to six a year (to allow for turf recovery, aeration, and overseeding), including two Metropolitan Opera ('Met') productions and two New York Philharmonic ('Philharmonic') productions. These performances are considered permissible, in significant part, because audiences do not exceed 80,000, and events are rescheduled if weather is bad and the turf is wet. If the Great Lawn were damaged, according to the City, New Yorkers would lose something 'sublime'. ${ }^{57}$

In light of the importance of the governmental interest (the sublime Great Lawn), the fact that the permitting scheme is content neutral (i.e. not based on the content of the speech of the Council), and the fact that the City had offered alternative venues that could accommodate the expected size of the rally, District Court Judge William Pauley refused to enjoin the City to give a permit to the Council to rally on the Great Lawn. The alternative avenues for communication offered to the Council were (a) to hold a smaller rally on the East Meadow of Central Park, or (b) hold the rally in Flushing Meadows in the borough of Queens or Van Cortland Park in the borough of the Bronx, neither of which are on the island constituting the borough of Manhattan where the RNC was to take place.

Regarding the question of a public forum, we have here a refusal to grant a permit for a political rally to occur during the RNC in a public park, which is a 'traditional public forum'.58 The Supreme Court has frozen the development of its public forum doctrine historically in a manner that does not adequately account for more contemporary spatial developments, such as shopping malls or airports. ${ }^{59}$ Even by limiting legal recognition of public fora to those spaces prominent when this juridical doctrine initially emerged in the 1930s, a park is a public forum. ${ }^{60}$ First Amendment rights should be on their strongest grounds when their exercise occurs in a public forum.

As for the governmental interest in preserving the grass, a damaged lawn can be considered a 'secondary effect' of the exercise of First Amendment rights in a public forum. In 1939, however, when New Jersey sought to prevent

57 National Council of Arab Americans v. New York, (2004), supra note 56, pp. 263-265.

${ }^{58}$ Hague v. CIO (1939), supra note 46.

59 PEA v. PLEA (1983), supra note 46; Hudgens v. NLRB 424 US 507 (1976); International Society for Krishna Consciousness, Inc. (ISKCON) v. Lee, 505 US 672 (1992); Lee v. ISKCON, 505 US 830 (1992).

${ }^{60}$ PEA v. PLEA (1983) supra note 46; Hague v. CIO (1939) supra note 46. 
people leafleting in the public streets in order to prevent litter-also a secondary effect deriving from the exercise of First Amendment rights in a public forum - the Supreme Court invalidated the leaflet ban as a violation of the right of free expression, arguing that "streets are natural and proper places for the dissemination of information and opinion". 61 Although cleaning the streets might impose greater economic responsibilities on the state, they were understood to be a cost that a democratic society bears.

Today, the post-Fordist raison d'être for the Great Lawn as a main attraction in Central Park is as an environment for cultural productions for ticketed patrons of the arts, and as an attraction for visitors to the city. The value of this space has changed. In light of the Lawn's post-Fordist purposes, its aesthetics have become particularly significant, as Judge Pauley's extended discussion of hearty Kentucky blue grass and sophisticated turf maintenance regimes attests. The aesthetic project of creating an environment suitable for the consumption of culture - a primary goal for the post-Fordist city means that unfortunate secondary effects of speech and its potentially disruptive possibilities - the role of litter in Schneider $v$. State - can now suffice to justify the regulation of expression or its removal to other spaces.

Democratic politics actually seems to count against the constitutional right to protest within post-Fordist aesthetic sensibilities. A protest of the sitting president's policies certainly counts as political speech. Mid-twentieth century, political speech was considered to be the most important speech to protect. ${ }^{62}$ Nevertheless, the political nature of the protest does not seem to cause Judge Pauley to hesitate in sustaining the denial of a protest permit to the group. In fact, if we consider his reference to the past of massive antinuclear rallies as the 'dust bowl era' of Central Park, it appears that there may even be an affective aversion to democratic politics in his opinion. While New York City's fiscal crisis in the mid-1970s caused upkeep of its parks, including Central Park, to be under-funded, Pauley's opinion creates a negative aesthetic association between the exercise of democratic rights and dirt that resonates with post-Fordist mentalities of governance placing heavy emphasis upon 'cleaning up' the city. ${ }^{63}$ The post-Fordist purpose of the Great Lawn is to produce cultural events like a Dave Matthews concert (which had over 85,000 patrons), a Met concert, or a Disney movie premiere, and these purposes have displaced demonstrations of democratic strength.

The New York Times article reporting on the Disney movie premiere of 'Pocahontas' on the Great Lawn referred to Central Park as 'Disney's Newest

61 Schneider v. State, 308 US 147 (1939).

62 A. Meikeljohn, Free Speech and its Relation to Self Government, New York: Harper 1948.

63 Rosenzweig \& Blackmar 1992, supra note 56, pp. 501-504, observe that in the 1970s, Central Park's decline was attributed to usage by teenagers or Puerto Ricans, when in fact the Park's problems were fundamentally economic. During the fiscal crisis, city budgets and workforces were slashed so that, according to one study, by 1982, New York's parks had accumulated almost $\$ 3$ billion in deferred maintenance needs. 
Park', in its title. ${ }^{64}$ Of course, it is not legally true that Disney owns Central Park, although between 70,000 and 100,000 entered the aesthetic world of Disney that night on the Great Lawn. The truth of the article's title lies in the way that it captures the Disneyfication of New York City, and the Disneythemed purposes that the Great Lawn served so capably that night. It may also refer to another aspect of the Disney experience. As criminologists Clifford Shearing and Philip Stenning point out, in Disney World, control is embedded within the very structures of the park. ${ }^{65}$ Disney introduced some of that security-consciousness to the Great Lawn premiere since, as previously noted, this was the first free park event to require tickets. Ticketing is a method of social control. One can control admission to those who are ticketed. One can control the numbers who are admitted by controlling the number of tickets circulated. And one can control the timing of the event by canceling it, and rescheduling it, if it is ticketed.

Therefore, one of the distinguishing factors in Pauley's opinion between the cultural and commercial events of a Dave Matthews show that attracts 85,000 , and a political demonstration hoping to attract 75,000 , is that the former is ticketed. If the protest were ticketed like the Disney premiere then some of the city's and the judge's worries could be alleviated. Pauley worries that the demonstration could prove too popular, attract more people than anticipated, and "overwhelm the police and destroy the Great Lawn". ${ }^{66} \mathrm{He}$ is also sympathetic to the city's concerns that there was no rain date for the rally. If the protest were more like a commercial event in terms of its methods of control, then it appears that Pauley would have been more willing to require the city to grant the permit since the rally's numbers could be controlled and ticket holders could be admitted to a rain date if it were canceled due to rain or a wet lawn. A political rally, however, is different from a commercial event - particularly one aspiring to demonstrate mass support. It hopes to attract as many people as possible, and it constructs its political meaning through its citations to its location, its date (this demonstration would occur rain or shine because of the symbolic significance of the date for civil rights), and its juxtaposed proximity to the RNC. At mid-twentieth century, commercial speech was not considered to enjoy full First Amendment protection. It was considered to be an aspect of commerce. ${ }^{67}$ While a movie is not merely commercial, it appears that a political demonstration suffers in terms of its First Amendment protection to the degree that it lacks methods of control innovated by Disney that have become more generalised in the large quasi-cultural, quasi-commercial events that are currently permitted on the Great Lawn. In this respect, the Great Lawn is a dimension of 'Disney' regarding the techniques or mentalities of its

${ }^{64} \mathrm{~F}$. Lee, June 11, 1995, supra note 45.

65 C. Shearing \& P. Stenning, 'Say “Cheese!": The Disney Order that is not so Mickey Mouse', in Private Policing, eds. C. Shearing \& P. Stenning, London: Sage 1987, pp. 317-323.

66 National Council of Arab Americans v. New York (2004), supra note 56.

67 Valentine v. Chrestensen, 316 US 52 (1942); Pittsburgh Press Co. v. Pittsburgh Human Relations Commission, 413 US 376 (1973). Today, commercial speech receives much greater First Amendment protection: 44 Liquormart, Inc. v. Rhode Island, 517 US 484 (1996). 
governance. As architect Michael Sorkin has written, "See you in Disneyland!".

Also important to Judge Pauley's reasoning was the city's offer of alternative avenues of communication. These included the offer of a smaller rally in Central Park's East Meadow, or locations in Queens or the Bronx. A smaller rally, while 'expressive', certainly contradicts the purpose of a mass protest to demonstrate how widespread popular opposition is to the Bush administration's policies. The size of the rally is part of its message. This would be appreciated under more democratic aesthetic perceptions.

The other alternative locations offered for the anticipated size of the Council's protest were not even on the island of Manhattan, which is the very center of New York and the site of the Republican Convention. This evinces a very different aesthetics of speech than was recognised in so many of the Supreme Court's mid-twentieth century decisions. The latter frequently made reference to the potential for disruption or the likelihood of unpleasant and caustic attacks when First Amendment rights were exercised in a democracy. ${ }^{68}$ Moreover, Justice Roberts rejected the idea that one's right to "liberty of expression in appropriate places [could be] abridged on the plea that it may be exercised in some other place". ${ }^{69}$ Today, it seems sufficient to satisfy a court that a group was able to express themselves, even if they have to voice their opinion far away from the target of their speech, in another place. In other words, today, as long as a group can voice its message, the First Amendment has not been violated. ${ }^{70}$ By considering remote locations for protests as satisfying First Amendment requirements, courts minimise and contain the potentially disruptive effects of speech as they prevent the possibility of political confrontation. This, in turn, helps to maintain the current order and its distribution of shares within an established and policed partition of the perceptible. ${ }^{71}$

These developments in lower courts' use of the time, place and manner test to analyze the question of place for protests tracks the zoning mentality of the Supreme Court's secondary effects jurisprudence regarding sexual expression. In the situation of political protest, lower courts are permitting the zoning of protest to places where the effects of the speech will be mitigated and less disruptive of the mega-event being hosted by the postFordist city. During the middle of the twentieth century, the Supreme Court recognised the potential for disruption when free speech rights are exercised. With the zoning of protest under the 'place' prong of the legal test to evaluate the constitutionality of time, place, and manner regulations, we can say that the right to free speech is becoming disarticulated from the project

${ }^{68}$ Terminiello v. Chicago, 337 US 1 (1949); New York Times v. Sullivan, 376 US 254 (1964).

69 Schneider v. State (1939), supra note 61.

${ }^{70}$ See also: Coalition to Protest the Democratic National Convention v. City of Boston (2004), supra note 53.

${ }^{71}$ Rancière 1999, supra note 49. 
of democracy, and is becoming reinscribed within a neoliberal juridical framework taking shape through these lower court decisions.

Today, the exercise of First Amendment rights is being conditioned upon their domestication within the post-Fordist city as one more zoned attraction or as an act of cultural production. The democratic and disruptive capacities of freedom of speech are being policed and controlled by being zoned and displaced from the demonstrators' target or those whom the demonstrators might want to interpellate. When demonstrators refuse to be contained in these ways, they are subjected to forms of violence and torturous treatment at the hands of police, as shown by the events of February 15th. Demonstrations of democracy are not part of the neoliberal, post-Fordist city's regime of rightful visibility.

\section{Conclusion}

In this paper, I have situated lower level court cases addressing the right to protest in public spaces within the context of shifts in urban political economy. Cities responded to the urban fiscal crisis of the 1970s by trying to raise revenue from non-residents - visitors or tourists. Cities became sites of consumption and entertainment destinations. They created different zones for different market niches, such as sports, the arts, museums, or festival marketplaces. They also took up zero tolerance, QOL policing to remove signs of economic distress and to create an aesthetic of safety to help market themselves to suburban visitors accustomed to shopping malls or Disneyworld.

The Supreme Court gave cities the legal tools to remove sexually oriented businesses from targeted districts by allowing cities to zone such establishments to contain their deleterious "secondary effects." This is how, for example, New York City cleaned up Times Square to make the city more compatible with Disney's brand image. Over the last few years, lower courts have used similar legal techniques to zone the right to protest out of the city's post-Fordist public spaces. This has been done in order to contain the potentially disruptive effects of a protest upon a city's efforts to create environments conducive to various types of consumption. Or, potentially disruptive effects of demonstrations are zoned away from a city's production of mega-events that generate visitor revenue, market a city in the global interurban competition for tourism, and prove that a city is mega-event capable. A rally must not disturb the mood Lincoln Center has attempted to create for opera enthusiasts in a public plaza, nor damage the Great Lawn in Central Park where large-scale concerts and movie premieres have been held.

Urban governance now works to create zones for tourists and consumers of 'culture,' and legal rulings share this aesthetic sensibility. This sensibility, however, moves legal reasoning differently under conditions of post-Fordism than during the middle of the twentieth century when the Supreme Court 
was attuned to how the exercise of free speech rights could lead to disruption. Fifty years ago, the Supreme Court interpreted dispute, unrest, anger, or a 'verbal cacophony' as signs of the strength of democracy. ${ }^{72}$ Today, lower level court decisions supporting the zoning or penning of protest to contain its effects indicate the emergence of a neoliberal juridical regime. Under this neoliberal juridical regime, the right to free speech is becoming disarticulated from the practice of democracy. Now, as long as one has the opportunity to 'express' oneself in a demonstration zone, one's right to free speech has been recognised. On the one hand, parades celebrating 'culture' are permitted to march in the post-Fordist city. On the other hand, manifestations of democratic strength are zoned away from post-Fordist entertainment enclaves. Or, the state frames one's act of expression with razor wire.

- The Amsterdam Law Forum is an open access initiative supported by the VU University Library -

72 Terminiello v. Chicago (1949), supra note 68; Cohen v. California, 403 US 15 (1971). 
